\title{
The Constitutionality of Prorogation
}

\section{Eric Adams*}

Friar: I hear thou must and nothing may prorogue it / On Thursday next be married to this county

Juliet: Tell me not, friar, that thou hears't of this / Unless thou tell me how I may prevent it. ${ }^{1}$

At 10:20 a.m. on 4 December 2008 - some forty minutes after Prime Minister Stephen Harper entered Rideau Hall to request that the Governor General, Michaëlle Jean, prorogue Canada's fortieth Parliament - the media reported an exciting development: the front doors opened. Reporters began to speculate that the meeting had been decisive, and an anxious nation awaited the Prime Minister's appearance to announce the Governor General's decision. But then, other than the descent of a few errant snowflakes, nothing happened. "It's been 6 minutes since you reported the front door opened - what's going on over there?" a desperate commentator pleaded on the National Post's live blog. ${ }^{2}$ For over thirty minutes the doors remained curiously ajar, and then - at 11:01 a.m. - they closed. When the Prime Minister finally did emerge nearly an hour after that, having spent a total of two and a half hours inside Rideau Hall, he informed Canadians that the Governor General had agreed to follow his advice and prorogue (or suspend) Parliament until 26 January 2009.

We do not know what transpired during the Prime Minister's meeting with the Governor General. Nevertheless, I argue that there is constitutional significance in one of the things we do know - the length of time the Prime Minister spent in Rideau Hall. The key, in my view, is not that the Governor General decided one way or the other, but that she exercised discretion in making her decision. The Governor General had, in other words, a choice to make. We can take comfort in the merit of her decision, but so should we also recognize the importance of the moment of decision itself. To be sure, the constitutional events of December 2008 revealed stark levels of constitutional misunderstanding among the Canadian public and, perhaps more disturbingly, media, opinion makers, and politicians. Bombarded, as we are, by the political culture of the United States (especially in an election year in that country), civic confusion concerning the differences between parliamentary democracy and the American presidential system should not be surprising. Canadians are still growing accustomed to repeated minority governments at the national level and the constitutional nuances that follow from that reality: votes of confidence that matter, shifting parliamentary alliances and coalitions, and an increased role for the Governor General in ensuring compliance with the constitution. The events of December 2008 helped to clarify more than obfuscate Canada's constitutional conventions. In addition, these encounters with, and disagreements about, our constitutional traditions, conventions, and norms continue the ongoing process of fashioning a vibrant and reflexive democratic constitutionalism. In other words, constitutional crises can be good for us.

Let me begin by sketching the constitutional laws and conventions governing the Governor General's decision to prorogue Parliament. Our constitutional tradition, as is well known, combines formally justiciable constitutional laws with politically derived, unwritten constitutional conventions. As a matter of constitutional law, the Constitution Act, 1867 provides that "Executive Government and Authority of and over Canada... [vests] in the Queen" just as it also contemplates that much of that authority will be executed by the Governor General "acting on behalf and in the Name of the Queen." It is the Governor General, according to the 
Constitution, who will select the "Queen's Privy Council for Canada,"4 appoint Senators, Lieutenant Governors, and Judges of the Superior Courts, ${ }^{5}$ and summon and dissolve the House of Commons. ${ }^{6}$ The specific power to prorogue Parliament is unmentioned in the Constitution, but it was well understood by the framers to fall within the prerogative of the Crown. As Blackstone had explained, "[a] prorogation is the continuance of the parliament from one session to another, as an adjournment is the continuation of the session from day to day. This is done by the royal authority." Indeed, as the Crown's Letters Patent Constituting the Office of Governor General of Canada make clear, the Governor General will "exercise all powers lawfully belonging to Us in respect of summoning, proroguing or dissolving the Parliament of Canada." In short, the Governor General alone possesses the constitutional power to prorogue Parliament.

Of course, those discretionary prerogative powers have long been circumscribed by a combination of legislation, orders-in-council, and constitutional convention. "In legal theory," Eugene Forsey points out, "the discretion of the Crown is absolute ... but the actual exercise of the power is everywhere regulated by conventions." Such conventions are unwritten and informal rules which emerge from political practice. ${ }^{10}$ With the legitimacy bestowed by reason and time, they solidify into traditions the breach of which can lead to political and constitutional crisis. Some of the most vital features of our constitutional system exist only as convention. The Constitution Act, 1867, for example, carries no provisions relating to the prime minister, cabinet, political parties, or the practices of responsible government. It was nonetheless understood by all at Confederation that the Governor General would, in the normal course of politics, follow the advice of the duly elected ministers of government in exercising his or her constitutional functions." "Whatever the constitutional rights of the crown," W.P.M. Kennedy writes, "they can be exercised in Canada, but through responsible ministers, as this is the method by which these rights find expression wherever responsible government exists."12 In this way, the exercise of executive power under the constitution remains firmly attached to and circumscribed by democratic ideals.

Notwithstanding their significant role in shaping constitutional practice, constitutional conventions, by their nature, create scope for legal uncertainty. Their status as unwritten rules of practice gives them flexibility and nuance, but also renders their content ill-defined and contestable. For this reason, A.V. Dicey famously dismissed the subject of conventions as "not one of law but of politics, [which] need trouble no lawyer or the class of any professor of law."13 Canadian lawyers and professors of law do not have that luxury. The Supreme Court of Canada has long recognized that Canada's constitution is necessarily comprised of both written and unwritten elements, which includes constitutional conventions. ${ }^{14}$ The Court's recognition of a constitutional convention requiring substantial provincial consent to amend the Constitution Act, 1867 paved the way, for example, for the final round of negotiations and compromises that led to the passage of the Constitution Act, $1982 .{ }^{15}$ Of course, like Dicey, the Court maintains that constitutional conventions, unlike constitutional laws, are political in the sense that they are not enforcable by the judiciary. Instead, "the sanctions of convention rest with institutions of government other than courts, such as the Governor General or the Lieutenant Governor, or the Houses of Parliament, or with public opinion and ultimately, with the electorate."16 As a result, conventions continue to animate the crucial workings of government, but they are not subject to judicial review in the strict sense. If the courts play a more influential role in recognizing and giving expression to their content than Dicey imagined, it is still the public which determines the consequences of breaches of constitutional convention.

What about the Governor General's decision to prorogue Parliament in December 2008? Did she appropriately follow constitutional convention in accepting the advice of her prime minister, or did she transgress a deeper set of constitutional values in allowing herself to be manipulated by the Prime Minister's partisan machinations? In this case, the elastic nature of conventions is neatly demonstrated by the fact 
that scholars and pundits from either perspective have claimed with equal vigour to have the authority of constitutional convention on their side. Critics argue that by acceding to the request to prorogue, the Governor General has set a dangerous precedent whereby any government in danger of losing a vote of confidence can simply pull the plug on Parliament, evade the judgment of the House of Commons, and wield power in defiance of the fundamental convention of responsible government: that our political executive enjoys the confidence of a majority of our elected parliamentarians..$^{17}$ Indeed, the precedent would be troubling if that is what it represents. I do not think that it does.

Let me return to those opened and closed doors of Rideau Hall. We can reasonably infer, given the length of the meeting, that the Governor General did not agree to the Prime Minister's request as a matter of obligatory or ceremonial formality. In other words, the Governor General could have said no, and probably should have, had the Prime Minister not also committed to reconvening Parliament in six weeks to deliver a budget and face a vote of confidence. Constitutionally, the House of Commons must meet at least once every twelve months; the Prime Minister could have requested a parliamentary suspension of much longer duration. ${ }^{18}$ In these circumstances, it was entirely appropriate for the Governor General to take into account the relatively short period of the requested prorogation. If the majority of members of the House of Commons had continued to have no confidence in Mr. Harper's government, they would have had the opportunity to express that view in January 2009. We should assume that these factors weighed in the calculus of the Governor General's decision to prorogue Parliament. That decision was the correct one, not because the coalition was illegitimate or undemocratic (both specious and ill-founded accusations), but because it respected the request of a prime minister who had won a confidence vote a week earlier and who had agreed to return to face the Commons after a six-week delay.

The most significant aspect of the Governor General's decision, however, was that she took time to consider her options. By deliberating, the Governor General protected the most important elements of the prerogative power the ability to refuse unconstitutional requests and to act without partisan interest to protect the constitution. The precedent that has been set, in other words, is an artful and judicious one: it reaffirms the Governor General's role in protecting the fundamental conventions of the constitution, while it simultaneously respects the ideals of responsible government and shields the Crown from the firestorm that would have erupted had she refused the Prime Minster's request. This is not to say that the Governor General must always select the road of least controversy. Indeed, in those rare instances in which the Governor General must refuse the unconstitutional advice of her ministers, there will always be political controversy. This is the nature of politics. Because politics, in a sense, creates the conventions which guide the Governor General's decisions, she is not at liberty to disregard political reactions insofar as they elucidate the conventions at issue. But it is crucial to remember that constitutional conventions and constitutional politics are not one and the same. It is the constitution - its rules and conventions - that must inform the Governor General's decisions, not the messy partisan politics that will attach itself to, and may indeed be the cause of, any contentious constitutional dispute.

What is the use, you might ask, of constitutional conventions if they deliver less than certain answers at the moments when they are needed most? Indeed, there have long been calls - and we are hearing them again - to codify constitutional conventions into positive law and to formalize the rules under which the Governor General operates. There are good reasons, beyond the allure of tradition, for keeping our constitutional conventions as they are - unwritten, flexible, and the subject of occasional controversy and disagreement. The ability to adapt to new circumstances has long recognized as one of the benefits of the common law. Unwritten constitutional conventions similarly enable the Governor General to respond to new and unanticipated situations moored to principle but not constrained by prescribed text. Moreover, it is in such moments of constitution- 
al debate about our conventions that we help to shape fundamental aspects of our constitutional law without recourse to courts and judges. Our reactions as politicians, scholars, and citizens to political controversy confirm or reorient the conventions that guide constitutional practice. While the December crisis gave rise to inflamed rhetoric about illegitimate and undemocratic political coups, so too did it create the space for others to challenge those assertions, and articulate the deeper constitutional norms which govern Canada's parliamentary tradition.

Like the famous King-Byng dispute before it, the constitutional meaning attached to Harper-Jean will take shape over time. That, in itself, signals a healthy virtue of Canadian constitutionalism. Ultimately, for better or worse, we live with the constitutional conventions we create for ourselves.

\section{Notes}

* Eric Adams, Faculty of Law, University of Alberta. I thank Greg Clarke at the Centre for Constitutional Studies for several stimulating conversations during the constitutional events of December 2008, and for organizing the panel at which this paper was first delivered.

1 Romeo and Juliet, IV, i.

2 See "Live Blog: Mr. Harper Gets His Christmas Wish as Parliament Suspended" (4 December 2008) National Post <online: http:// network.nationalpost.com/np/blogs/posted/ archive/2008/12/04/live-blog-mr-harper-goes-torideau-hall.aspx $>$.

3 Constitution Act, 1867 (U.K.), 30 \& 31 Vict., c. 3, ss. 9, 10, reprinted in R.S.C. 1985, App. II, No. 5 (CanLII).

$4 \quad$ Ibid. at section 11.

$5 \quad$ Ibid. at sections 34, 58, and 96.

$6 \quad$ Ibid. at sections 38 and 50.

7 Wayne Morrison, ed., Blackstone's Commentaries on the Laws of England (London: Cavendish, 2001) at 138. And, of course, as the preamble to the Constitution Act, 1867 announces, the uniting provinces desired "a Constitution similar in Principle to that of the United Kingdom.”

8 Letters Patent Constituting the Office of Governor General of Canada (Imperial Order-in-Council, proclaimed in force 1 October 1947) at section VI. The provision is unaltered from previous versions in 1931, 1905, and 1878. See Letters-Patent
Constituting the Office of Governor-General of the Dominion of Canada, 1878 in W.P.M. Kennedy, ed., Documents of the Canadian Constitution, 1959-1915 (Toronto: Oxford University Press, 1918) at 696.

9 Eugene A. Forsey, The Royal Power of Dissolution of Parliament in the British Commonwealth (Toronto: Oxford University Press, 1968) at 3.

10 See generally Andrew Heard, Canadian Constitutional Conventions: The Marriage of Law and Politics (Toronto: Oxford University Press, 1991).

11 See generally A.B. Keith, Responsible Government in the Dominions, 2d ed. (Oxford: Clarendon Press, 1928).

12 W.P.M. Kennedy, The Constitution of Canada: An Introduction to its Development and Law (London: Oxford University Press, 1922) at 379.

13 A.V. Dicey, Introduction to the Study of the Law of the Constitution, 8th ed. (London: MacMillan, 1915) at 30.

14 Reference Re Alberta Legislation, [1938] S.C.R. 100; Switzman v. Elbling, [1957] S.C.R. 285; Reference re Secession of Quebec, 1998 SCC 793, [1998] 2 S.C.R. 217 (CanLII).

15 Reference re Resolution to Amend the Constitution, 1981 SCC 25, [1981] 1 S.C.R. 753 (CanLII).

16 Ibid. at 883.

17 See Andrew Heard, “The Governor General's Decision to Prorogue Parliament: Parliamentary Democracy Defended or Endangered?" Points of View No. 7 (January 2009), online: Centre for Constitutional Studies <http://www.law.ualberta. $\mathrm{ca} /$ centres/ccs/uploads/PointsofView7.pdf $>$.

18 Canadian Charter of Rights and Freedoms, Part I of the Constitution Act, 1982, being Schedule B to the Canada Act 1982 (U.K.), 1982, c. 11 at section 5 (CanLII). 